\title{
Lingga Isaq Hunting Park as A Basis of Sustainable Management: A Socio-Economic Study
}

\author{
Cut Maila Hanum ${ }^{1 *}$, Hadi Sukadi Alikodra ${ }^{2}$, Agus Priyono Kartono ${ }^{2}$, Rinekso Soekmadi ${ }^{2}$ \\ ${ }^{1}$ Graduate Program of Tropical Biodiversity and Conservation, Faculty of Forestry, Bogor Agricultural University, \\ Dramaga Campus, Bogor, West Java, Indonesia 16680 \\ ${ }^{2}$ Department of Forest Resource Conservation and Ecotourism, Faculty of Forestry, Bogor Agricultural University, \\ Dramaga Campus, Bogor, West Java, Indonesia 16680
}

Received December 10, 2017/Accepted April 27, 2018

\begin{abstract}
The management of conservation and socio economic condition of surrounding communities are always connected each other. The similar case can be found in Lingga Isaq Hunting Park (LIHP), one of the conservation areas located in Aceh Province. This study is aimed to examine socio-economic conditions of the community around LIHP as the basic data to improve the effectiveness of area management. Data were collected through a technical survey by interviewing 120 respondents who were randomly selected from two sub-districts namely; Bintang and Linge where each sub-district consists of three villages. The results showed that $52.57 \%$ of total community income is obtained from coffee plantation which planted within the LIHP area. The level of hunting park contribution to community income, indicates that the communities are highly relies on LIHP area. However, the level of community participation is very low either individually or as a group. The participation is limited to securing and maintaining the area from the forest fires. Local community wisdom is still applied in land clearing and hunting method within the area. Supervision, fostering partnership, relationships between communities and LIHP managers are required to improve community capacity and conservation awareness. As in return, it will reduce community dependence and utilization of LIHP's land. This study also recommends the need to actively engage with non-governmental organisation or civil society as part of LIHP's sustainable management. It is intended to improve community welfare and provide opportunities for local wisdom development in the management of LIHP.
\end{abstract}

Keywords:forest conservation, sustainable management, socio economic, Lingga Isaq Hunting Park

*Correspondence author, email:maila_kamal@yahoo.com

\section{Introduction}

Hunting park is a conservation area that has management function as an area that can be utilized its potential and services for animal hunting, protection of buffer zone system, and preservation of plant's, animal's diversity and nature uniqueness (Ditjen PHKA 1996). However, the facts showed many problems faced in the management of conservation areas in Indonesia including management of a hunting park. The problem of conservation area management is influenced by several factors, including internal condition such as legality status of the area that has not been fully agreed among the parties, the completion of boundary designation process, and area management that has not been well organized. The challenges from external conditions include land demand due to development dynamics (Ditjen KSDAE 2015).

Development and management of sustainable and effective hunting park require consideration of socioeconomic characteristics of the community. According to Sanderson et al. (2002), the effectiveness in conservation planning requires complex considerations including biological, social and economic factors that are integrated into one region. Serageldin (1996) argues that sustainability is seen in three dimensions as a triangular framework namely sustainability of economic, social and ecological. The success of management depends on the level of support and appreciation to the conservation area by surrounding communities (MacKinnon et al. 1993).

Characteristics and behaviour of communities that interact with forests in utilising forest resources to meet their daily needs are necessary and important information for formulating forest management strategies (Nugroho et al. 2008). Understanding the uniqueness of the conservation area and the people living in and around the conservation area is critical for the successes of any program in the conservation area (Pagdee 2006). Furthermore, Padgee argues that this has been proved by Dong Keng's community forest management in Thailand that the management program based on socio economic community condition that seems efficient and results in positive outcomes for the community. 


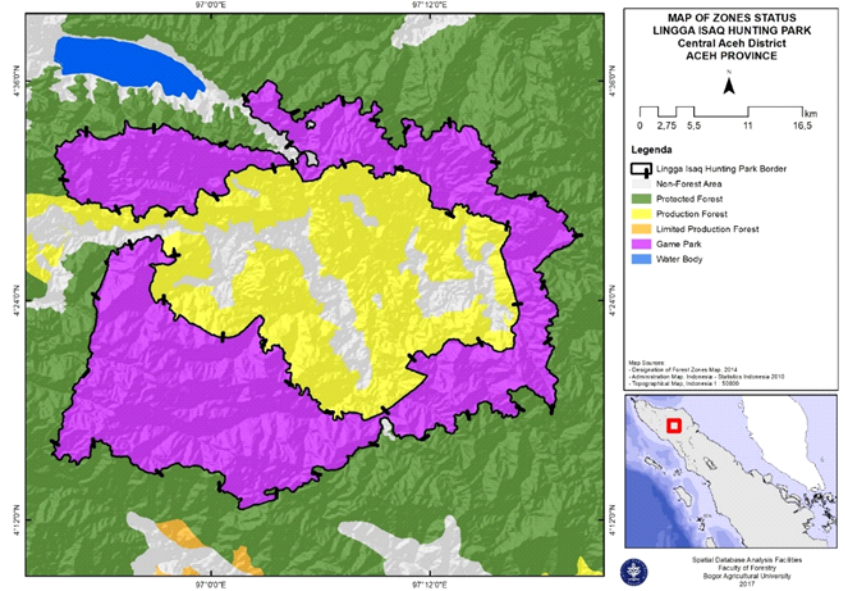

Figure 1 Map of Aaa status of Lingga Isaq Hunting Park of Aceh Province.

Area of Lingga Isaq Hunting Park (LIHP) was designated as a hunting park based on Decree of The Minister of Agriculture Numbered 70/KPTS/UM12/1978 dated 7 February 1978. Based on the Decree of Forest And Water Area Year 2014, LIHP is located in Kabupaten Aceh Tengah of Aceh Province, with the area of 86,320.14 ha. Administratively, the largest part of LIHP is located in Bintang and Linge sub-districts with the number of villages directly adjacent to LIHP area are 33 villages which are part of Bintang, Linge, Lut Tawar, and Pegasing sub-districts. LIHP has a unique shape and location, from the area's form and its location point of view, LIHP is cut off by two state road lanes. The outer part of the area is directly adjacent to the protected forest, while the inside is adjacent to production forest area, namely industrial timber plantation (HTI) of PT Tusam Hutani Lestari (Figure 1).

The LIHP provides substantial services for the community and the surrounding environment, including ecological functions (such as maintaining hydrological functions, nutrient cycles, and carbon production), consumptive benefits (meat producers, honey, rattan, and medicines) and non-consumptive benefits (hunting, nature tourism, culture, research, genetic, and aesthetic sources). In another sides, surrounding environment and regional development gives influences to LIHP ecosystem. For instance, the influences from surrounding environment include utilization of natural resources by the community and community participation in managing LIHP. Influence of regional development to LIHP is determined as local development policy, for example infrastructure development, tourism development, accessibility, and land use planning.

The existence of LIHP cannot be separated from the people who live in the forest area. Community around the forest will generally interact with the forest to meet their living needs. According to Awang (2004), community interaction around forests with the forest is characterized by collecting forest products such as foodstuffs, firewood, animal feed, tubers, and other forest services. Furthermore, Andayani (2008) states that interaction between community and forest, can be positive or negative. Positive interaction happened if the interaction is mutually beneficial for both the community and for the forest, whereas the negative interaction happened if the interaction is harmful to one side, to the community or forest conservation, neither both. Community interaction with forests indicates the community's dependence on the existence of the forest in the long term (forest sustainability). Therefore, it is expected that communities participate and have a role in look after the forest resources that they need. This condition is an opportunity for managers to cooperate with communities in the management area. Forest products that are utilized by the community are expected to generate awareness to maintain the forest area (Lewerissa 2015). According to Sharma (1990), the long-term success of protected areas requires a shift in management philosophy that combines resource management with a sensitive understanding of the social and economic needs of local communities.

Communities around the LIHP area interact more with the area for crops and harvesting non-timber forest products (NTFP). Community activities will certainly affect the condition of the region. Therefore, the socio-economic condition of the community needs to be studied to know the form of interaction and actual activities of the community in the area, so the role of the community in managing the area effectively can be known. The purpose of this study was to examine the socio-economic conditions of society, community interaction and community support in the management of LIHP. This study will further become the basis for consideration in designing the management plan of LIHP.

\section{Methods}

Research framework Therville et al. (2018) revealed that loss and lack of social acceptance of protected areas call into question the ability to reach long-term biodiversity conservation objectives. To address this, conservation group have moved the protected areas management from segregative to integrative models. The segregative model sees protected areas as human exclusion zones, while the integrative model considers the integration of conservation, development projects and multiple partnerships with local stakeholders within and outside protected areas. Furthermore, currently protected areas are managed with a consideration on its surrounding landscape including the community. This approach is well known as a single social ecological system (SES). To achieve the long-term objective of biodiversity conservation, upgrading protected areas management by harmonizing with the needs and aspirations of their constituencies (Pringle 2017), including community surrounding protected area, related stakeholders, and policies; become a must.

Based on above shifted management model of protected areas from segregative to integrative by integrating and harmonizing the needs and aspirations of their constituencies, including community surrounding, related stakeholder and policies (Pringle 2017), this study come with theoretical framework of this research is interaction (reciprocal relationship) between LIHP region and communities surrounding area. As mentioned earlier, according to Awang (2004) and Calfucura (2018), the interaction between communities surrounding with the forest 
is characterized by harvesting timber and non-timber forest product. This characteristic also happen to LIHP, where LIHP contributes to ecological functions (such as maintaining hydrological functions, nutrient cycles and carbon production), and economic function such as consumptive benefits (meat producers, honey, rattan, and medicines), and non-consumptive benefits (hunting, nature tourism, culture, research, genetic, and aesthetic sources). The environment surrounding LIHP will use the services provided by LIHP for example utilization of natural resources by the community and community participation in managing LIHP.

With regards to stakeholder participation and policies regulated, we identified management of LIHP directly driven by local government and national government through government policy. In addition, management of LIHP also driven by surrounding communities. Both government policy and community surrounding will entirely utilize ecological and economic function of LIHP. The expectation result from community involvement in managing LIHP include the increase of regional domestic product, the increase of community welfare, and possibility in avoiding losses and damage caused by to natural disaster. As specified by Andayani (2008) on classification of community surrounding and forest interaction, the interaction pattern among community surrounding and LIHP and the purpose to achieve the biodiversity protection functions are described in the research framework (Figure 2).

Research location and the time of data collection The study was carried out in Lingga Isaq Hunting Park (LIHP), Aceh Tengah District of Aceh Province, starting on August 2016 until January 2017. Selection of sampling location for socio-economic conditions study was based on the distance of the villages to LIHP. According to administrative border, most of LIHP area is located under Bintang and Linge sub-districts management. Hence, the sampling area were located in both sub-districts which consisted of Atu Payung,
Konyel, and Dedamar villages in Bintang Sub-district; and Mungkur, Gewat and Kemerleng villages in Linge Subdistrict (Figure 3).

Data collection method Type and sources of data collected on social economic aspect of community surrounding LIHP are secondary and primary data (Table 1). The secondary data collection was obtained from Aceh Tengah District agencies namely Statistical Bureau, Forestry Agency, Planning Agency, district government offices, and village government offices. The secondary data include demography, land use, land cover, and LIHP institutional management. The primary data collection was done through interview by using structured interview (Esteberg 2002). Interviews were conducted to determine the socio-economic conditions of community, community interaction, and community support in the management of LIHP. The method used to determine the number of community samples is was based on Slovin formula (Sevilla \& Consuelo 2007) as follow as Equation [1]:

$$
n=\frac{N}{1+N e^{2}}
$$

Note: $\mathrm{n}=$ number of sample (120 respondents), $\mathrm{N}=$ number of population (total number of households in six targeted villages of two sub-districts: 741 households), e = error (standard error 0,1)

Based on the equation obtained, the number of respondents was 120 respondents from two sub-districts namely; Bintang and Linge sub-districts with each subdistrict consists of three villages. Each village represented by 20 respondents.

Data analysis method Socio-economic conditions of the community were analysed through quantitative descriptive and qualitative descriptive. Quantitative descriptive analysis is used to obtain information about the characteristics of the community around LIHP. Qualitative descriptive analysis is

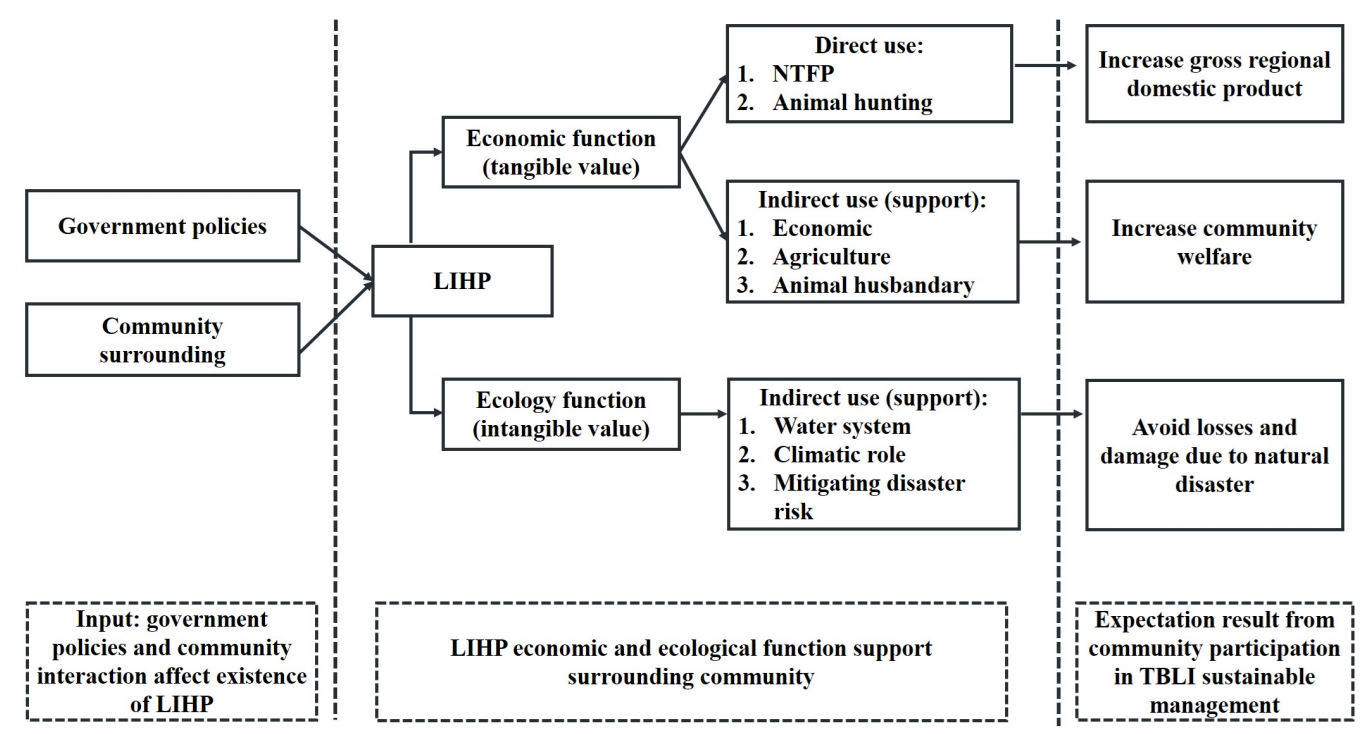

Figure 2 Framework of this study. 
used to get an explanation about the level of interaction and problems of the community around LIHP. Data processing was using Microsoft Excel and SPSS 16.0 to generate the box plot analysis.

Level of dependency The level of community dependence on LIHP area can be calculated as shown in Equation [2]:

Dependent level $=\frac{\text { Total income from TBLI }}{\text { Total income community }} \times 100 \%$

The dependent category is: not dependent at all $=0 \%$, low $=$ $1-33 \%$, medium $=34-66 \%$, high $=67-100 \%$

Income contribution from coffee plantation to total community income was calculated as shown as Equation [3]:

Coffee contribution $=\frac{\text { Total income of coffee plantation }}{\text { Total community income }} \times 100 \%$

Projection level of dependency for next ten years Projection of dependency community surrounding to LIHP was using the approach of population growth of community surrounding LIHP, by using projection for next ten years from BPS (2015) on population and population density. This figure is further linked to level of needs to access or directly utilize the LIHP area.

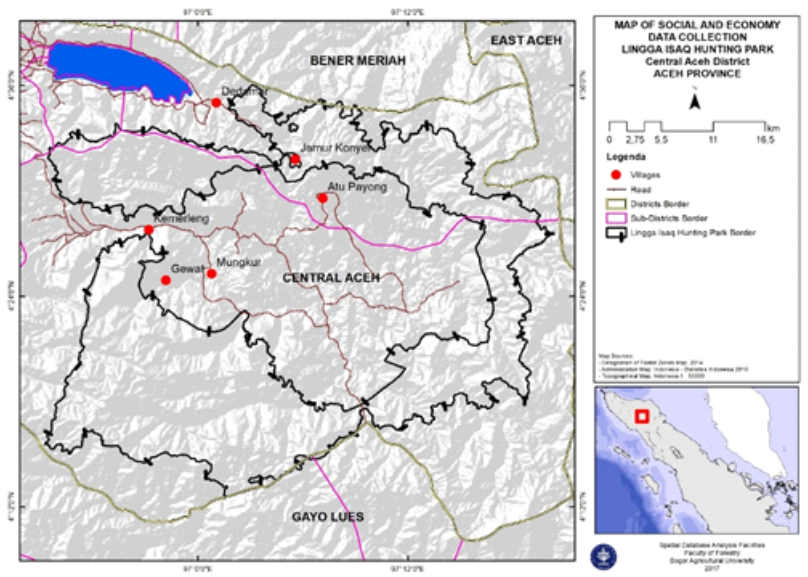

Figure 3 Map of research location.

\section{Results and Discussion}

The existence of LIHP cannot be separated from the people who live in the forest area. Administratively, the largest part of LIHP is located in Bintang and Linge sub-districts with a total number of villages directly adjacent to sub-district for 11 villages, Linge Sub-district 18 villages, and Lut Tawar Sub-district was four villages.

LIHP has a high potential of flora and fauna with some key protected species found including, tiger sumatran (Panthera tigris sumatrae), sumatran orangutans (Pongo abilii), sambar deer (Cervus unicolor), deer (Muntiacus muntjak), jungle goat (Capricornis sumatrensis), sun bears (Halarctros malayanus), Rafflesia sp., tusam (Pinus merkusii Aceh strain). LIHP is also the upstream of four watersheds (DAS) namely Jambo Aye Watershed, Meurebo River Basin, Tripa River Basin, and Peusangan River Basin (BKSDA 2014). These watersheds are essential for community in upstream, along the watershed until in coastal area along the Aceh Province.

Characteristics of communities surrounding LIHP Characteristics of the community provide an overview of the communities profile, who are interact with LIHP areas. These characteristics include age group, level of education, family structure and responsible, land ownership, and community livelihood. Furthermore, these characteristic parameters affect the community surrounding behaviour in managing and utilizing the LIHP's services and level of dependency on LIHP. Despite of relationship the parameters to LIHP, among the parameters itself have interrelated relationship that may influence one to another.

Age group and level of education The age description represents the level of community productivity in various activities, such as farming, pine-tapping, hunting, and collecting honey. The average age will give a picture of the productive age or not. Based on the research results, the characteristics of people who interact with hunting park area ranged between $22-80$ years old. The result of the analysis also shows that most of the respondent age in research location is around $37-48$ years old. The age range shows that most of the respondent age category is productive age (15-64 years old).

Table 1 Data collection method

\begin{tabular}{|c|c|c|c|}
\hline Aspects & Variable & Type of data & Method \\
\hline \multirow[t]{2}{*}{ Demography } & $\begin{array}{l}\text { Population, age group, } \\
\text { education level, income }\end{array}$ & Secondary & Desk study \\
\hline & $\begin{array}{l}\text { Family structure and } \\
\text { responsible }\end{array}$ & Primary & Interview \\
\hline \multirow[t]{2}{*}{ Spatial } & Land use & Secondary & Desk study \\
\hline & Land cover & Secondary & Desk study \\
\hline Institutional & $\begin{array}{l}\text { LIHP institutional } \\
\text { management }\end{array}$ & Secondary & Desk study \\
\hline \multirow[t]{3}{*}{$\begin{array}{l}\text { Community Interaction to } \\
\text { LIHP }\end{array}$} & $\begin{array}{l}\text { Level of dependency to } \\
\text { LIHP }\end{array}$ & Primary & $\begin{array}{l}\begin{array}{l}\text { Interview and direct } \\
\text { observation }\end{array} \\
\end{array}$ \\
\hline & Community support & Primary & $\begin{array}{l}\text { Interview and } \\
\text { observation }\end{array}$ \\
\hline & $\begin{array}{l}\text { LIHP contribution to total } \\
\text { income }\end{array}$ & Primary & Interview \\
\hline
\end{tabular}


People around the park area depend on the forest for coffee plantation. The coffee plantation work requires a lot of manpower. Therefore, most of people who interact with the forest are those who are still classified into the productive age category. The age range of 71-80 years old is the lowest age group of respondents and categorised as an old group, their interaction with the forest area is minimum.

The result of boxplot analysis on distribution (interval) of age of communities whose are interacting with the LIHP area is presented in Figure 4. The boxplot shows that the age variation in Mungkur Village is the narrowest, while the age variation in Atu Payung Village is the widest compare to other five villages. This can be interpreted that the age interval distribution in Mungkur Village is very small or the communities' age are relatively similar. In contrast, the age interval variation in Atu Payung Village is the most vary from young to old age group. Interestingly, Atu Payung Village also has the highest number of young age group.

Data about education level provided information about general condition of community around the LIHP. Educational levels affect the pattern of communities to utilise, manage, and relay on forest resources. As the education is one of the main indicators in the human development index, the area with population that has a high literacy rate is the main asset for region development and progress. The biggest distribution of respondent's education level is elementary school or sekolah dasar (SD) and junior high school or sekolah menengah pertama (SMP). These indicate that level of education in the region is good based on literacy indicators. A good level of education will provide convenience in various activities, such as assistance, capacity building and various management and protection of natural resources and environment activities. The level of education of community around LIHP is presented in Figure 5.

Community's livelihood Community livelihood information described the community profession (livelihood) in the research location. The main profession of the community in the LIHP area greatly affects the sustainability of LIHP management. Overall, about $44 \%$ of people's livelihoods around the area are rice field farmers, about $33 \%$ is coffee plantation farmer, $13 \%$ is working as pine tappers, and $10 \%$ of community earned from hunting, livestock, and collecting non-timber forest products. The results showed that the whole community has a coffee farm within the park area. It was showed that the people around area have dependence on the area for coffee plantation. The distribution of community's works is shown in Figure 6.

Income description is generated through each respondent from various type of livelihoods. A large amount of income provides easiness in earning their live. On the contrary, the less amount of income, the more difficult in fulfilment the life needs. According to Figure 6, all communities in six villages earned income from coffee plantation. Other activities such as farming, ranching, and sap tapping are the alternatives income in every village. Animal hunting does not become a source of income because the community does not sell the hunted animal they got rather used it for daily meals instead.

The monthly income come from various sources of income ranging from IDR300,000-IDR1,500,000. However, most of the average monthly income is less than IDR1,500,000. Only a small percentage of the average monthly income of the community is $\geq$ IDR $1,500,000$. Mostly, the average monthly income is below the regional minimum wage or upah minimum regional (UMR) per month of Aceh Tengah District, which is around IDR 2,500,000. According to Aceh Governor Regulation Number 72 Years 2016 Dated 27 October 2016, community around LIHP could be categorised as poor people. The income of villagers from various sources of income per year is shown in Figure 7.

Family structure and responsible Family structure and responsible discusses about number of family member in each household in study area that reflect to economic dependency to the head of family (house holder). In 2004, the number of households which were located around the LIHP area from three District was around 7,814 households (BPS

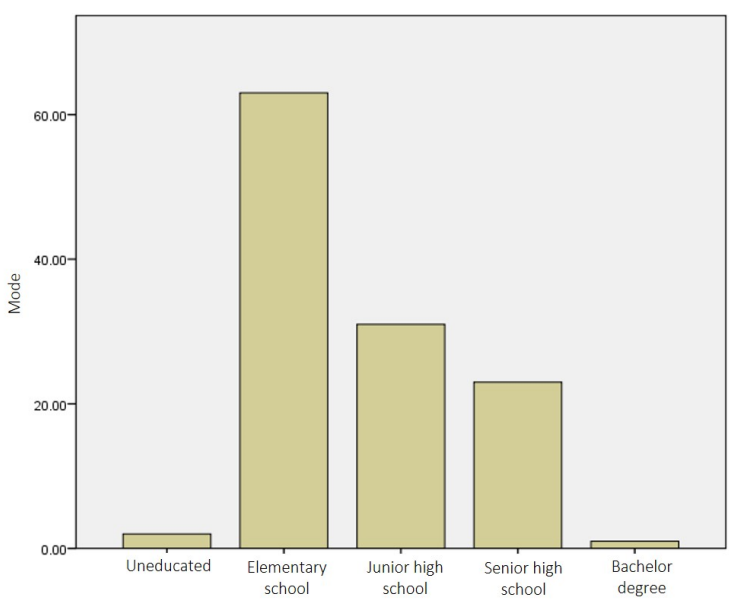

Figure 5 Education level of community surrounding Lingga Isaq Hunting Park.

Figure 4 Respondent's age data distribution. 
Kabupaten Aceh Tengah 2005). The latest data on 2013 showed the number of households around LIHP from those three kecamatan was increased to 9,477 households (BPS Kabupaten Aceh Tengah 2015). The increase in the number of households in the last ten years in the kecamatan around the hunting park is $21 \%$ of the population in 2004 . This study shows that the increasing number of people will increase the chance of interaction of natural resource utilization within LIHParea.

The number of dependents in one family will provide a high burden in the fulfilment of basic life needs. Vice versa, the less number of dependents, will lower the burden for fulfilment the basic needs, such as clothing, foods, and housing. According to Kadir et al. (2012), the number of dependents in family can affect the productivity and creativity of the head of the family in work. In addition, according to Nugroho et al. (2008), the number of family dependents also shows a proportion in resource collection. The results showed that most of the dependents in a family amounted three to four people. Few respondents had a family number more than seven people. Respondents who have only one family dependent were those in age range of 25-30 years old. The number of family dependents of LIHP is shown in Figure 8. In addition, level of dependency in family of each village in study area is presented in Table 2.

Land use of LIHP and community land ownership The LIHP area is adjacent to the production forest area or hutan tanaman industry (HTI) by Tim Utan Plantation of company named PT Tusam Hutani Lestari, protected forest and other designated areas (Figure 1). Based on the characteristics of the location, shape, physical boundaries, and conditions of land use around the area, it is very likely to get various pressures through the activities of people living in villages around LIHP as well as from the broader community using the provincial road facilities that cut LIHP area. This condition requires an approach to managing the area from various threats. According to Sharma (1990), the long-term success of protected areas requires a shift in management philosophy that combines resource management with a sensitive understanding of the social and economic needs of local communities.

The main livelihood of communities around LIHP are agriculture farmers, especially rice and plantation. Normally each family has one hectare rice field. As for the area of plantation, each family also have average one hectare farm. Sometimes we can find families with land area of 2.5-3 ha coffee plantation. All respondents have coffee plantations within the LIHP area, indicating that the community depends on the area for the sustainability of the coffee business as a source of community income. In addition, most of communities also have an abundant land about one hectare/family.

Above condition requires an approach in managing the area from various threats. According to Sharma (1990) and Calfucura (2018) the long-term success of conservation areas requires a shift in management philosophy that combines resource management with a sensitive understanding of the social and economic needs of local communities. Furthermore, Bulte et al. (2003) states approaches that can be applied in the management of conservation areas with surrounding communities is through 1) approach to community values and norms through threats and moral persuasions of people in an economic perspective, 2) regulatory and control approaches, and 3) economic incentive approach.

Community interaction with LIHP The community interacts with the forest as a form of social activities to meet their needs. The interaction between community and forest is in the form of land use within the forest area and collecting forest products. Community activities around LIHP are the coffee plantation, hunting, pine tapping, and harvesting other forest products such as honey and rattan. The culture of utilizing forest resources by surrounding communities has been ongoing since before the area was designated as a conservation area. The community's dependence on LIHP area to grow coffee in the area is seen from the contribution of the coffee plantation to the income of the community around

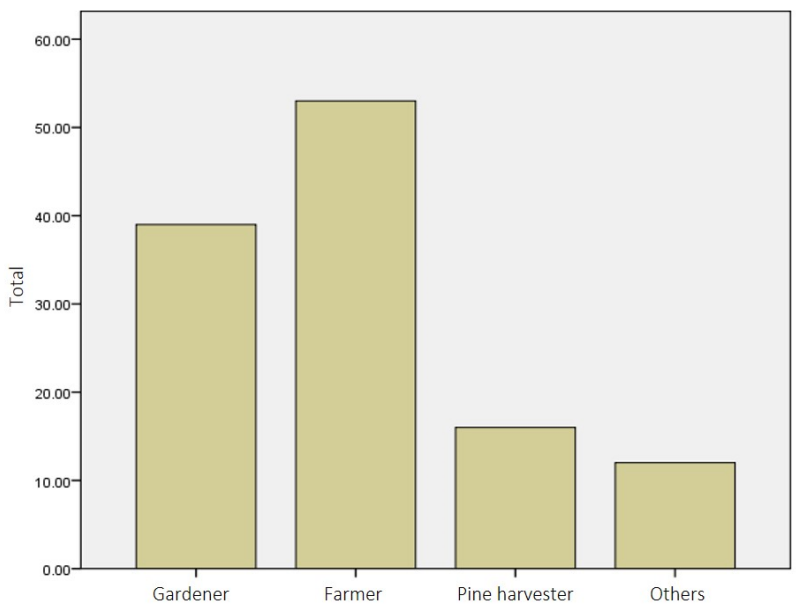

Figure 6 Distribution of community profession.

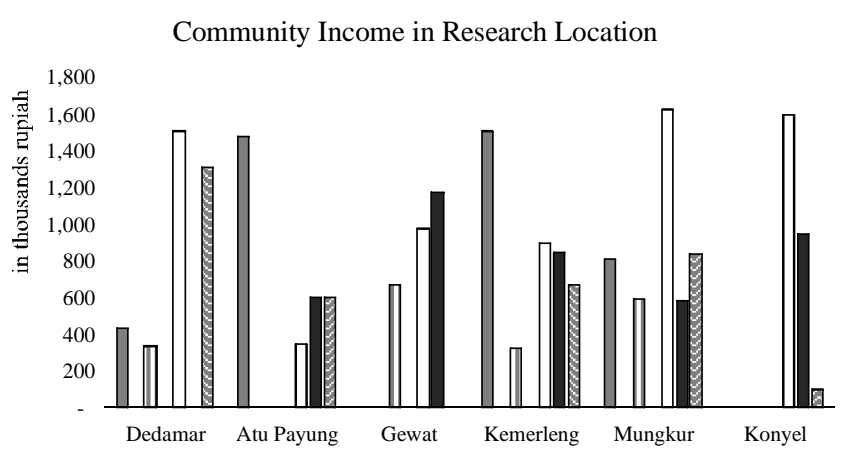

Figure 7 Community income per village from various resources. Crop farming ( $\square$ ), animal hunting ( $\square$ ), livestock $(\square)$, honey collecting (⿴囗口), plantation ( ), resin tapping $(\square)$, others $(\boldsymbol{\square})$. 
LIHP. The average community income from coffee plantation is as much as IDR12,697,135 per year. The income contribution of the community from planting coffee is $52.57 \%$ of the total income of the community. The high level of community dependence has many implications. The public may penetrate the hunting area to expand the coffee plantations owned.

According to Ahmad et al. (2012) land use activities around protected areas can increase the pressure on the region in the end. However, on the other hand, the needs of these communities can increase awareness of the benefits of LIHP area. Thus, the community can be invited to cooperate in managing the LIHP area. In theory, protected areas will

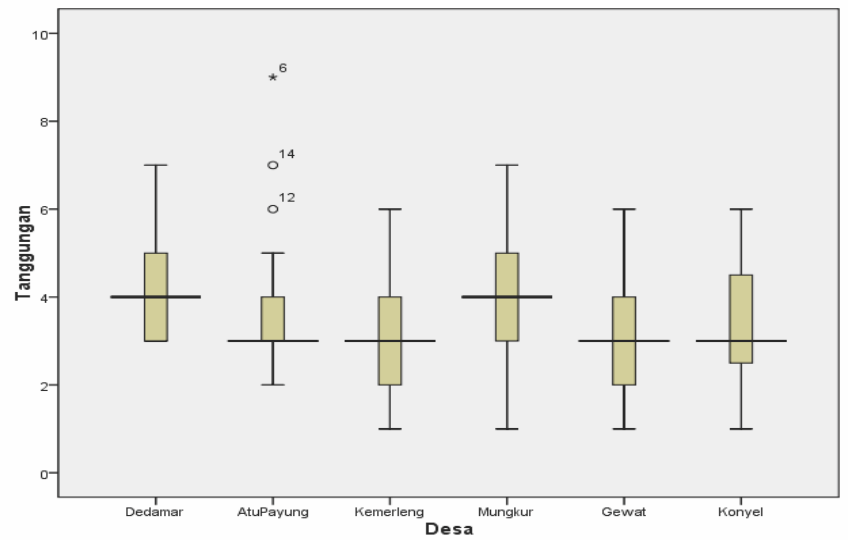

Figure 8 Distribution of family dependents number in each village. reduce the economic costs of communities by limiting the ability to use areas for agriculture, logging, and hunting. But communities can also benefit from tourism activities, good infrastructure investments, and valuable forest ecosystem services (Robalino 2007; Ferraro \& Hanauer 2011). Principally, protected areas suppress forest clearing and forest degradation at the border area by limiting land use change and extractive activities (Miranda et al. 2014).

Social interaction between community in the utilisation of natural resources within and around the area LIHP is low. This is because the community around LIHP in utilizing individual resources about $43 \%$, while $41 \%$ of people do not agree to utilize natural resources conducted in groups. Collection of natural resources in groups usually occurs in the activities of harvesting honey in the area. The condition of society towards the social interaction of the community in LIHP is presented in Figure 9.

The interaction of natural resource utilization by the surrounding community gives a little influence on the LIHP area's integrity. Disturbance to the territorial integrity is partly due to continued land clearing activities. This is because the community's dependence on forests is still high, such as land clearing into coffee plantations, wild grazing, and wild hunting. The result of the land cover analysis shows in Table 3. The change of land cover from secondary forest to shrub area of 90.56 ha and plantation forest encrusting 53.38 ha of shrub. The result of the land cover analysis showed the change of land cover. Based on land cover map of year 2015 it was found that the change in secondary forest covers mostly changed into scrub, savanna, or grassland.

Based on the actual condition of the area, the strategy

Table 2 Dependent level of community surrounding LIHP

\begin{tabular}{|c|c|c|}
\hline Subdistric & Village & Level of dependence \\
\hline \multirow[t]{9}{*}{ Linge } & Jamat & High \\
\hline & Reje Payung & High \\
\hline & Delung Skinel & Medium \\
\hline & Linge & Low \\
\hline & Kute Reje & High \\
\hline & Gewat & High \\
\hline & Lumut & High \\
\hline & Pantan Nangka & High \\
\hline & Ise-Ise & High \\
\hline Bintang & Serule & High \\
\hline \multirow[t]{14}{*}{ Lut Tawar } & Asir-Asir & Low \\
\hline & Bujang & Low \\
\hline & Hakim Balee Bujang & Low \\
\hline & Kenawat & Low \\
\hline & Toweran Antara & - Low \\
\hline & Toweran Toa & Low \\
\hline & Toweran Uken & Low \\
\hline & Gunung Suku & Low \\
\hline & Rawe & Low \\
\hline & Takengon Timur & Not dependent at all \\
\hline & Bale Atu & Low \\
\hline & Pedemun & Low \\
\hline & Merah Mersa & Low \\
\hline & Takengon Barat & Not dependent at all \\
\hline
\end{tabular}


through the approach of landscape integration with the concept of agroforestry can be applied for improving and stabilizing people's livelihoods, while reducing the pressure on the conservation area and increasing the habitat of some wild species, as well as improving the connectivity of landscape components (Ashley et al. 2006). The potential for agroforestry to be effectively utilized requires policy and institutional managers to provide clear incentives to communities to plant and protect trees that contribute to both ecosystem functions and community livelihoods. Vedeld $e t$ al. (2012) explain that managers need to provide more tangible benefits to local communities and offer long-term partnerships. According to MacKinnon et al. (1993), conservation area management should be conducted within a social framework that can benefit the community. Communities are given access to sustainably manage resources with certain limitations and participate in maintaining the LIHP area. Vedeld et al. (2012) recommend the basics for the realization of collaboration and conflict

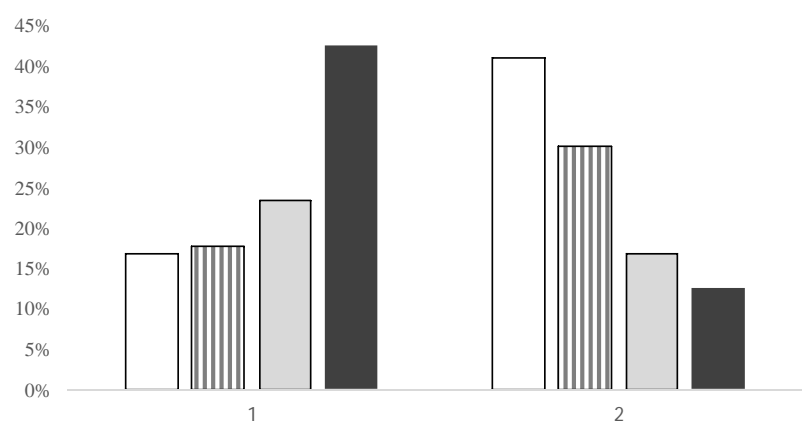

Figure 9 Participation level in LIHP management. Note : 1 = Individually uses of forest resources; 2 = Group uses of forest resources Strongly Disagree ( $\square$ ), Disagree ( $\square$ ), Agree ( $\square$ ), Strongly Agree ( $\square$ ). resolution with communities, namely increasing regional benefits, reducing management costs by collaborating with communities, enhancing legitimacy and social relationships, and robust biodiversity protection policies.

Giving access and trust to the community is expected to be a solution to prevent the encroachment of the area due to the expansion of the coffee plantation. Local people have the knowledge capacity to utilise biological natural resources that have unintentionally conserved, but the community does not gain the trust of the government so that the capacity of local knowledge is not involved in programs made by the government (Tambunan 2008). To solve tenure and justice problems for local communities and indigenous and tribal peoples within or around the forest in the context of community welfare and the preservation of the government's forest function, the Ministry of Environment and Forestry set Regulation Numbered P.83/Menlhk/Setjen/Kum.1/10/2016 on Social Forestry through conservation partners.

Community support for the existence of LIHP The sustainability of conservation area very depends on the support of community surrounding the conservation area. Without community support, there will be no long-term conservation areas protected (MacKinnon et al. 1993). Based on results of the study, about $50 \%$ of the community did not participate in the management of LIHP. A total of $32 \%$ of the community agreed to participate in the preparation of management plan and area's security. However, most of the communities less participated in a group to support regional management $(29 \%)$ and did not participate personally in supporting the management of $\operatorname{LIHP}(33 \%)$.

Based on the above explanation, it can be concluded that the comprehensive community participation in managing the area is absolutely needed. Because, currently the maximum level of community participation is only engage in the preparation of management plans and limited to wildfire suppression and prohibiting hunting activity by outsiders

Table 3 Land cover changes between year 2006 and year 2015

\begin{tabular}{|c|c|c|c|c|c|c|}
\hline \multirow{3}{*}{ Land Cover } & \multicolumn{6}{|c|}{ Area } \\
\hline & \multicolumn{2}{|c|}{2015} & \multicolumn{2}{|c|}{2011} & \multicolumn{2}{|c|}{2006} \\
\hline & ha & $\%$ & ha & $\%$ & ha & $\%$ \\
\hline $\begin{array}{l}\text { Primer Dry } \\
\text { land forest } \\
\text { Second Dry }\end{array}$ & 40454.94 & 0.47 & 40454.94 & 0.47 & 40454.94 & 0.47 \\
\hline $\begin{array}{l}\text { land forest } \\
\text { Forest }\end{array}$ & 37626.72 & 0.44 & 37717.28 & 0.44 & 37717.28 & 0.44 \\
\hline plantation & 5404.67 & 0.06 & 5458.05 & 0.06 & 5458.05 & 0.06 \\
\hline Shrub & 335.57 & 0.00 & 229.79 & 0.00 & 229.79 & 0.00 \\
\hline Open area & 0.66 & 0.00 & 0.00 & 0.00 & 0.00 & 0.00 \\
\hline Savanna & 2389.31 & 0.03 & 2389.31 & 0.03 & 2389.31 & 0.03 \\
\hline $\begin{array}{l}\text { Water body } \\
\text { Mixed Shrub } \\
\text { and Dry land }\end{array}$ & 70.78 & 0.00 & 70.78 & 0.00 & 70.78 & 0.00 \\
\hline forest & 37.49 & 0.00 & 0.00 & 0.00 & 0.00 & 0.00 \\
\hline Total & 86320.14 & 1.00 & 86320.14 & 1.00 & 86320.14 & 1.00 \\
\hline
\end{tabular}


villages. This type of participation is conducted in a group form by communities whose living in the villages surrounding the area. Individual awareness to participate in managing the area is very low. Sometimes, the community willing to participate if we give incentive to them. Participation in forest protection, resource use, and decisionmaking activities is an important means, especially if the groups recognize their potential for more effective forest management. However, the participative process has declined in many resource user groups (Chhetri et al. 2013). Furthermore, Andrande and Rhodes (2012) argued that the higher level of public participation, the higher level of compliance with protected area management policies. This has important implications for protected area management and demonstrates that incorporating local communities in management should be a key strategy to ensure the integrity of protected areas. Description of the conditions of community participation is presented in Figure 10.

The study results showed that $32 \%$ of people strongly agree to implement local wisdom in managing the area. About $38 \%$ of the people strongly agree that local wisdom can support the sustainability of conservation area management. During the dry season, most of communities (31\%) agreed to clear the lands without burning it. The communities understand that during the dry season; it will be vulnerable to forest fires if they clear the land by burning it. In addition, $38 \%$ of people also hunt traditionally with $41 \%$ agreed to maintain the water well. According to the community, the village government needs to issue a village regulation on biodiversity protection, because some communities strongly agree $(30 \%)$ that village governments need to implement regulations on biodiversity protection. The knowledge and values of local communities are considered as value for biodiversity conservation. Relationships between trust, reciprocity, and exchange, customs, norms and sanctions, and relationships within groups as social capital, are needed to shape individual

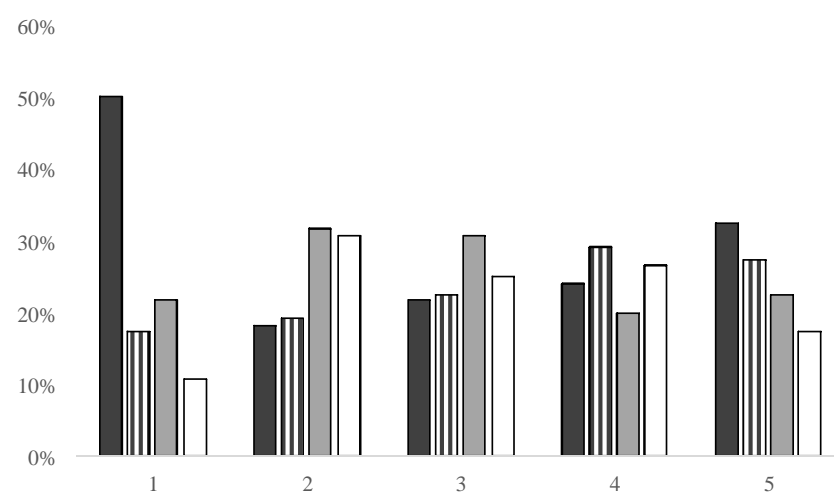

Figure 10 Public perception on interaction of community in the hunting park area with forest resources utilization. 1 = Participate in LIHP management, 2 $=$ Engage in management plan, 3 = Engage in area security, 4 = Group support in the area management, $5=$ Personally support management. Not participating ( $\square)$, less participate $(\square)$, participate $(\square)$, highly participate (口). action in achieving good results for biodiversity conservation (Pretty \& Smith 2004). An illustration of people's perceptions of local community wisdom on LIHP is presented in Figure 11.

The conflict between communities is still common in land uses. Most of the community (34\%) agreed that conflict is still common in the region. Most of the community stated that the conflict is related to utilization of timber forest products has never happened, because the community does not utilize timber forest products in the area. Furthermore, it is also known that the conflict between NTFP utilization between communities also does not occur. This indicates that the conflicts occurring in LIHP communities tend to be low. The community agrees if a conflict occurs within the area completed by the village institution, the village manager, and the relevant NGO. Although conflicts in society are low, there needs to be conflict prevention. According to Vedeld $e t$ al. (2012) current regional management culture is on the attitudes, values and norms that need to be changed through learning in how to work with local people, such interventions will help reduce the level of conflict. The conflict conditions in the communities around LIHP are presented in Figure 12.

Analysis of community dependence in next ten years Population growth and development dynamics require an integrated LIHP management strategy with communities around LIHP that has been there before LIHP designated as a hunting park in 1978. The importance of integration in the management of conservation area with the surrounding area is also argued by Therville et al. (2018), accelerated biodiversity loss and lack of social acceptance of protection areas call into question their ability to reach longterm biodiversity conservation objectives. To address this, management of protection area have moved from segregative to integrative models. Sayer et al. (2013), revealed the effectiveness of biodiversity protection is the necessity to integrate protection area with the its surrounding area, which can be done through a landscape approach.

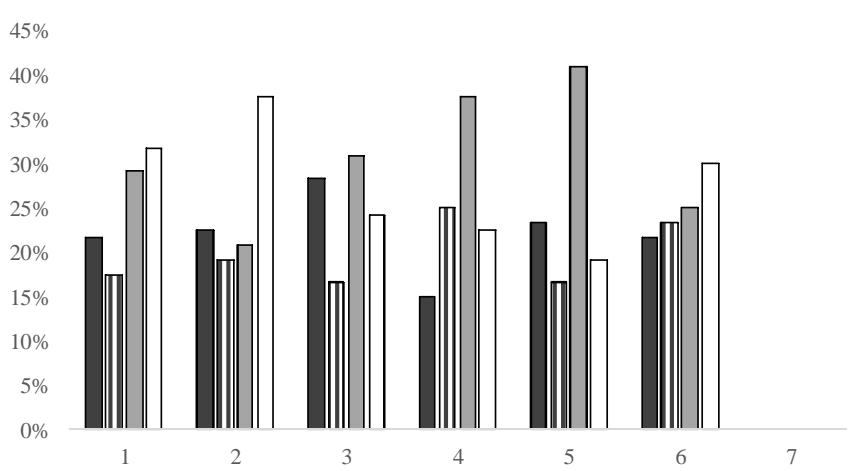

Figure 11 Community perception of their local wisdom in relation to LIHP. 1 = Community applied local wisdom, 2 = local wisdom supports sustainable management, 3 = Community land clearing without burning , $4=$ Community traditional hunt, $5=$ Community protect spring water, $6=$ Village government issues regulation of protected area.

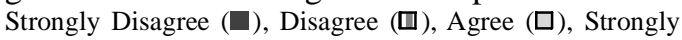
Agree (ㅁ). 


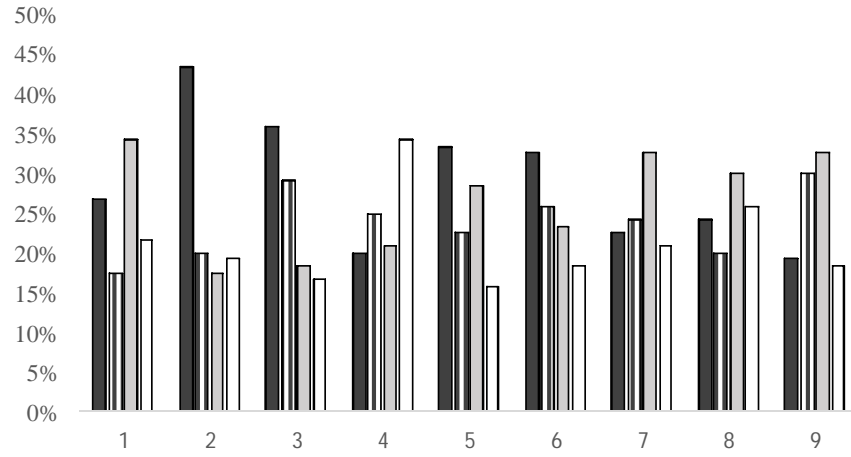

Figure 12 Conflict condition in community surrounding LIHP. 1 = Conflict often occurs in land use, $2=$ conflict often occurs in timber forest product utilization, 3 = conflict is common in the use of NTFP, 4 = Community is involved in conflict resolution, $5=$ Communities are involved in timber conflict conflicts, $6=$ Communities are involved in conflict in utilization non-timber, $7=$ Village institutions involved in resolving conflicts, $8=$ Area managers involved in resolving conflicts. Strongly Disagree (ם), Disagree

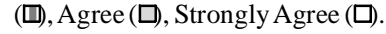

The management of conservation areas such as LIHP is closely related to the activities of the people around the area to meet their daily needs. They are hereditary to run the traditional life by utilizing the area. The people, especially in Linge and Bintang Sub-district have been utilizing natural resources within the area of Buru Park in the form of nontimber forest product, pine gum tapping, traditional hunting for meat, animals as collection and pets, rattan utilization, jeurenang rattan, aloes, bamboo, fish, honey, fruits and livestock grazing in the area. In addition, LIHP areas are provide various environmental services particularly water to community around the northern, eastern, western and also coastal areas.

With regards to the land status, LIHP is very unique because as it shaped is like a ring which consisted of production forests, other areas of use or area penggunaan lain (APL) and hunting park itself. Surprisingly, the middle part of LIHP is controlled by the community, and the areas are used as coffee plantation. This situation sometimes creates problem in managing the area, particularly the conservation area. Since the people of Aceh Tengah District are very famous for its Gayo coffee commodity, where the coffee has been reaching out to the international market with the worth price. It made the need for land to grow coffee is continuously grow and it leads to the land encroachment. Coffee plantation in the hilly area applied the steep terrain planting method and this caused threat to landslide in some areas of LIHP is quite high. The situation is exacerbated by the lack of clear boundaries in the field that make many people around the area who have not understood the location status of their coffee plantation, whether in the production forest or even in LIHP.

Based on data analysis and focus group discussion with the community in three sub-districts surrounding LIHP, the level of dependence of the community on the LIHP area varies from low (1-33\%) to high (67-100\%). In Linge Sub Ditrict, seven of nine villages are highly depending on LIHP, community in Bintang Sub-district is highly dependending on LIHP. However total twelve villages in Lut Tawar Subdistrict have low level dependency to LIHP and two villages namely Takengon Barat and Takengon Timur are not dependent at all to LIHP, as the location of both villages are the farthest from LIHP (Table 2). Overall, the level of community dependency to LIHP are high (Table 2) with the contribution of coffee to public income is about $40-80 \%$. At the moment, people have not been too dependent on LIHP yet, because the land is still adequate to support their livelihood activities. However, in some locations, outside of study area namely Jamat, Seureule, and Kute Reje villages, the condition is quite dangerous where the area of community coffee cultivation is not far with LIHP.

Based on density of the population, the dependence rate of community around the LIHP ranged from $0.7-2.4$ people $\mathrm{km}^{-2}$. The population growth trend for the next ten years is estimated will be less small, thus there will still be enough land available to support the coffee plantation and livestock in the region. The growth estimation is based on the percentage of children who will be the productive age force in the next ten years in these villages. is around $12-15 \%$ of the total number of the current population.

The solution to this problem is community empowerment through enhancing the competence of HHBK management, strengthening community economic institutions and networking with intensive assistance, counselling and training for land intensification and other activities. Activities with the improvement of people's mind set, community knowledge, skills, spirit, and creativity are channelled to the positive. The environmental campaign also very important starting from an early age because, in the next ten years, they will continue the community involvement with LIHP. Communication, coordination and cooperation with stakeholders such as relevant agencies, NGOs, research institutions and universities need to be encouraged to obtain a wise and effective formulation in the utilization of LIHP area that accommodates the needs of local communities including excavation and potential benefits the environment of Taman Buru for the welfare of the surrounding community. There should be efforts to achieve the target of ten years ahead with a priority scale.

Based on the results of our focal group discussion, we found that the lack of management of LIHP is the limitation of the community in the management. Local government and the community are not satisfied because the area of LIHP not provide an optimal benefit to their live, especially the people around the area. The community wants for the roles and benefits of the region to support their welfare. The priority of the management of the area is how the area can be managed by promoting the use of the area by applicable laws and regulations.

The main priority of management is the development of hunting tourism that is considered to answer the needs and challenges of the community around the area. Immediate efforts towards the development of hunting should be prioritized so that gradually the existence of the area can 
provide tangible benefits for local communities. An inventory of hunting animal potential and the determination of hunting species is immediately established and paralleled with the development of facilities and infrastructure that support the development of hunting tourism.

Based on inventory and regulation of the Minister of Forestry Number P.19/Menhut-II/2010 dated 6 April 2010, wildlife species that can be designated as hunting animals in LIHP in accordance with the potential survey results are red jungle fowl (Gallus gallus), Hystrix brachyuran, longtailed macaque (Macaca fascicularis), wild boar (Sus spp), deer (Cervus spp.), deer (Muntiacus muntjak), wild goat (Capricornis sumatraensis), and various bird species. Stocktaking is required for an inventory carried out by BKSDA Aceh with Balitbanghut Aek Nauli. The inventory result should include type of animal, number of animals, comparison of sex of animals, animal breeding season, animal season, age structure of animals, productivity of animal reproduction, and spreading of animals in LIHP.

After knowing the population condition and growth rate of hunted animal populations, then the hunting quota can be determined, as the compensation of new quota determination, special founding needed to support population of hunted animals that have been determined. Guidance of population by providing wildlife development area is needed to optimize support on population growth to ensure availability of hunting animals. In this area, adaptation cages and breeding for hunting animals, especially those imported from outside the region, can be built. In addition, can also be built supporting facilities for the availability of habitat components such as drinking places, food additives and others.

In relation to the components of wildlife habitat (food cover/shelter and water), the area of animal counselling is a refuge for wildlife, especially hunting animals. This area is also an area of hunting animal activity in the breed so that hunting animals can be kept awake. This area is also an ecosystem capable of supporting the preservation of protection block and hunting block.

The area of animal coaching in LIHP is planned to be $8,628.80$ ha or $9.95 \%$ of the total area of LIHP. This area is prepared and located in three areas in Jamat of 5,111.79 ha, in Kute Reje village with an area of $1,908.33$ ha and in Mungkur/Gewat area of 1,608.68 ha. The area of animal coaching is planned in such a way that it relates to the Buru Block and protection block, so its function as a balancing of hunting animal's population can be run well.

\section{Conclusion}

The contribution of LIHP area to support community's livelihood is high, particularly as the area for coffee plantation. The situation may cause negative implication as the community may penetrate the hunting area to expand their coffee plantation. The LIHP also contributes of NTFP and water resources for surrounding the community. Conservation of biodiversity in LIHP has special challenge as the surrounding communities are heavily dependent on them for various forest products and subsistence needs. Wealth status of the poor household, family size, agricultural income and education are the four major determinants of forest dependency in LIHP. Land utilization within LIHP by the community will potentially be a threat and pressure on the existence of the area. However, this situation may cause negative implication as the community may penetrate the hunting area to expand their coffee plantation. Our study found that the community is willing to participate in the management and protection of LIHP area as long as they receive tangible benefit. Our study also found that the local community is applying the environmentally friendly land clearing and animal hunting within the area (local wisdom) that effectively prevent any damaged to the integrity of the LIHP. However, given the high pressure from coffee market demand, there is a need to prevent people from increasing the area of coffee in LIHP area by introducing an NTFP wise utilization while optimizing the production of the existing land to reduce the risk of encroachment. Furthermore, in order to protect biodiversity on the LIHP area that has been transformed into a community coffee plantation, it is necessary to develop a model of community participation and community awareness programming through cooperation between managers and the community of planters to defend areas of wildlife corridors and areas with high biodiversity.

\section{Recommendation}

The human resources, budget and infrastructure that support the management of LIHP is still very limited. The plan to develop the LIHP as a hunting park models requires a resource upgrading which include capacity building and resource competence of LIHP managers and increasing involvement and community empowerment through conservation cadre programs, forest ranger partner, and firecaring communities. For budgetary support, the Ministry of Forestry may provide the financial support through the Unit of Forest Conservation Management (Kesatuan Pengelolaan Hutan Konservasi), public private partnership cooperation through hunting, and tourism development permits. With regards to research, forest protection, and biodiversity protection, technical assistance, and economic empowerment for communities, LIHP Manager can work together and with support from local and international nongovernment organizations. As for the development and infrastructure for the next ten years are more directed to the development of facilities of hunting and biodiversity protection such as boundary arrangement signs, patrol facilities, and information centre for visitor.

\section{Acknowledgement}

We would like to extend our sincerely gratitude to BKSDA Aceh; Team of Resort Bintang Area, Resort Linge, and Resort Isaq; community and head of Atu Payung, Dedamar, Konyel, Kemerleng, Mungkur and Gewat villages; forest ranger Mr. Aman Samin and Aman Sarija. As well as the support team Armia, Muhardi, Dedek, Ita, and the various parties that cannot be mentioned one by one.

\section{References}

[BKSDA] Balai Konservasi Sumberdaya Alam. 2014. Rencana Pengelolaan Jangka Panjang Taman Buru Lingga Isaq Kabupaten Aceh Tengah Provinsi Aceh 
2013-2023. Aceh: Balai Konservasi Sumberdaya Alam Aceh.

[BPS Aceh Tengah] Badan Pusat Statistik Kabupaten Aceh Tengah. 2005. Aceh Tengah dalam Angka. Aceh: BPS Kabupaten Aceh Tengah.

[BPS Aceh Tengah] Badan Pusat Statistik Kabupaten Aceh Tengah. 2015. Aceh Tengah dalam Angka. Aceh: BPS Kabupaten Aceh Tengah.

[Ditjen KSDAE] Direktorat Jenderal Konservasi Sumberdaya Alam dan Ekosistem. 2015. Pedoman Penilaian Efektivitas Pengelolaan Kawasan Konservasi di Indonesia. Management Effectiveness Tracking Tool. Jakarta : Direktorat Jenderal Konservasi Sumberdaya Alam dan Ekosistem.

[Ditjen PHKA] Direktorat Jenderal Pelestarian Hutan dan Konservasi Alam. 1996. Surat Keputusan Dirjen PHKA No. 129 Tahun 1996 tentang Pola Pengelolaan Kawasan Suaka Alam, Kawasan Pelestarian Alam, Taman Buru dan Hutan Lindung. Jakarta: Direktorat Jenderal Pelestarian Hutan dan Konservasi Alam.

Ahmad CB, Abdullah J, Jaafar J. 2012. Community activities around protected areas and the impacts on the environment at Krau Wildlife Reserve, Malaysia. Procedia-Social and Behavioral Sciences 68(2012):383 -394.https://doi.org/10.1016/j.sbspro.2012.12.235.

Andayani W. 2008. Pengelolaan Agroforestry. Yogyakarta:Fakultas Kehutanan UGM.

Andrade GSM, Rhodes JR. 2012. Protected areas and local communities: an inevitable partnership toward successful conservation strategies? Ecology and Society 17(4):14. http:dx.doi//org/10.5751/ES-05216-170414.

Ashley R, Russel D, Swallow B. 2006. The policy terrain in protected area landscape: challenges for agroforestry in integrated landscape conservation. Biodiversity and Conservation 15:663-689. https://doi.org/10.1007/ s10531-005-2100-x.

Awang SA. 2004. Dekonstruksi Social Forestry: Reposisi Masyarakat dan Keadilan Lingkungan. Yogyakarta: Bigraf Publishing.

Bulte EH, Kooten GC, Swanson T. 2003. Economic incentives and wildlife conservation. CITES Workshop on Economic Incentives and Trade Policy, Geneva.Chhetri BBK, Johnsen FH, Konoshima M, Yoshimoto A. 2013. Community forestry in the hills of Nepal: determinants of user participation in forest management. Forest Policy and Economic 30:6-13.

Calfucura E. 2018. Governance, land and distribution: a discussion on the political economy of community-based conservation. Journal Elsevier Ecological Economics 145:18-26. https://doi.org/10.1016/j.ecolecon.2017. 05.012 .

Chhetri BBK, Johnsen FH, Konoshima M, Yoshimoto A. 2013. Community forestry in the hills of Nepal: determinants of user participation in forest management. Forest Policy and Economic 30:6-13. https://doi.org/10.1016/j.forpol.2013.01.010.
Esterberg KG. 2002. Qualitative Methods in Social Research. Boston: McGrawHill.

Ferraro P, Hanauer M. 2011. Protecting ecosystems and alleviating poverty with parks reserves: "win-win" or tradeoffs? Environmental and Resource Economics 48(2):269-86. https://doi.org/10.1007/s10640-0109408-z.

Kadir A, Awang SA, Purwanto RH, Poedjiraharjoe E. 2012. Analisis kondisi sosial ekonomi masyarakat sekitar Taman Nasional Bantimurung Bulusaraung, Provinsi Sulawesi Selatan. Jurnal Manusia dan Lingkungan 12(1):1-11.

Lewrissa E. 2015. Interaksi masyarakat sekitar hutan terhadap pemanfaatan sumberdaya hutan di Desa Wangongira, Kecamatan Tobelo Barat. Jurnal Agroforestri 10(1):10-20.

MacKinnon J, MacKinnon K, Child G, Thorsell J. 1993. Pengelolaan Kawasan yang Dilindungi di Daerah Tropika. Yogyakarta: Gadjah Mada University Press.

Miranda JJ, Corral L, Blackman A, Asner G, Lima E. 2014. Effects of protected areas on forest cover change and local communities. Resources for the Future 1-34.

Nugroho BTA, Undaharta NKE, Siregar M. 2008. Interaksi masyarakat sekitar hutan terhadap pemanfaatan keanekaragaman hayati di awasan ekosistem hutan alami Bedugul-Pancasari, Bali. Biodiversitas 9(3):227-231. https://doi.org/10.13057/biodiv/d090316.

Pagdee A, Kim Y, Daugherty PJ. 2006. What makes community forest management successful: a meta-study from community forests throughout the world. Society and Natural Resources 19:33-53. https://doi.org/10. 1080/08941920500323260.

Pretty J, Smith. 2004. Social capital in biodiversity conservation and management. Conservation Biology 18(3):631-638. http://dx.doi.org/10.1111/j.15231739.2004.00126.

Pringle RM. 2017. Upgrading protected areas to conserve wild biodiversity. Nature 546: 91-99. https://doi.org/10.1038/nature22902.

Robalino J. 2007. Land conservation policies and income distribution: who bears the burden of our environmental efforts? Environment and Development Economics 12:521-33. https://doi.org/10.1017/S1355770X07 003671

Sanderson EW, Kent RH, Vedder A, Coppollo PB, Ward SE. 2002. A Conceptual model for concervation Planning Based on Landscape Spesies Requirements. Landscape and Urban Planning 58(2002):41-56. https://doi.org/10.1016/S0169-2046(01)00231-6.

Sayer J, Sunderland T, Ghazoul J, Pfund JL, Sheil DE, Venter M, Boedihartono AK, Day M, Garcia C, Oosten CV, Buck LE. 2013. Ten principles for a landscape approach to reconciling agriculture, conservation, and other competing land uses. Proceedings of the National Academy of Sciences of the United States of America. 
110(21):8349-8356. https://doi.org/10.1073/pnas. 1210595110.

Serageldin I. 1996. Sustainabiliy and the Wealth of Nations, First Steps in a Ongoing Journey. Environmentally Sustainable Development (ESD) Studies and Monpgrafhs. Series No 5. World Bank, Washington DC.

Sevilla, Consuelo G. 2007. Research Methods. Quezon City: Rex Printing Company.

Sharma U. 1990. An overview of park-people interaction in Royal Chitwan National Park, Nepal. Landscape and Urban Planning 19(2):133-144. https://doi.org/10.1016/ 0169-2046(90)90049-8.
Tambunan R. 2008. Perilaku konservasi pada masyarakat tradisional. Jurnal Harmoni Sosial 2(2):83-87.

Therville C, Mathevet R, Bioret F, Antona M. 2018. Navigating protected areas as social-ecological systems: integration pathways of French nature reserves. Regional Environmental Change18:607-618. https://doi.org/10. 1007/s10113-017-1231-4

Vedeld P, Jumane A, Wapalila G, Songorwa A. 2012. Protected areas, poverty and conflicts a livelihood case study of Mikumi National Park, Tanzania. Forest Policy and Economics21:20-1. https://doi.org/10.1016/ j.forpol.2012.01.008. 